\title{
The Use of Natural Compounds as a Strategy to Counteract Oxidative Stress in Animal Models of Diabetes Mellitus
}

\author{
Marcela Salazar-García ${ }^{1, *}$ and Juan Carlos Corona ${ }^{2, *(D)}$ \\ 1 Laboratorio de Investigación en Biología del Desarrollo y Teratogénesis Experimental, Hospital Infantil de \\ México Federico Gómez, Mexico City 06720, Mexico \\ 2 Laboratory of Neurosciences, Hospital Infantil de México Federico Gómez, Mexico City 06720, Mexico \\ * Correspondence: msalazar.investigacion@gmail.com (M.S.-G.); jcorona@himfg.edu.mx (J.C.C.); \\ Tel.: +52-55-52289917 (M.S.-G. \& J.C.C.)
}

check for updates

Citation: Salazar-García, M.;

Corona, J.C. The Use of Natural

Compounds as a Strategy to

Counteract Oxidative Stress in

Animal Models of Diabetes Mellitus.

Int. J. Mol. Sci. 2021, 22, 7009. https://

doi.org/10.3390/ijms22137009

Academic Editor: Tullia Maraldi

Received: 7 June 2021

Accepted: 23 June 2021

Published: 29 June 2021

Publisher's Note: MDPI stays neutral with regard to jurisdictional claims in published maps and institutional affiliations.

Copyright: (c) 2021 by the authors. Licensee MDPI, Basel, Switzerland. This article is an open access article distributed under the terms and conditions of the Creative Commons Attribution (CC BY) license (https:// creativecommons.org/licenses/by/ $4.0 /$ )

\begin{abstract}
Diabetes mellitus (DM) is a chronic metabolic disease characterised by insulin deficiency, resulting in hyperglycaemia, a characteristic symptom of type 2 diabetes mellitus (DM2). DM substantially affects numerous metabolic pathways, resulting in $\beta$-cell dysfunction, insulin resistance, abnormal blood glucose levels, impaired lipid metabolism, inflammatory processes, and excessive oxidative stress. Oxidative stress can affect the body's normal physiological function and cause numerous cellular and molecular changes, such as mitochondrial dysfunction. Animal models are useful for exploring the cellular and molecular mechanisms of DM and improving novel therapeutics for their safe use in human beings. Due to their health benefits, there is significant interest in a wide range of natural compounds that can act as naturally occurring anti-diabetic compounds. Due to rodent models' relatively similar physiology to humans and ease of handling and housing, they are widely used as pre-clinical models for studying several metabolic disorders. In this review, we analyse the currently available rodent animal models of DM and their advantages and disadvantages and highlight the potential anti-oxidative effects of natural compounds and their mechanisms of action.
\end{abstract}

Keywords: animal model; natural compounds; neuroprotection; oxidative stress; diabetes mellitus

\section{Introduction}

Diabetes mellitus (DM) is a chronic metabolic disorder characterised by insulin deficiency (pancreatic $\beta$-cell dysfunction) and insulin resistance. There are three widely accepted major forms of DM, including gestational DM, type 1 diabetes mellitus (DM1), and type 2 diabetes mellitus (DM2), which accounts for approximately $90 \%$ of all cases of DM. DM2 is associated with several factors, including chronic hyperglycaemia, hyperlipidaemia, and hypertension, as a result of insulin resistance or insulin deficiency [1,2]. The global prevalence of diabetes in 2019 was estimated at $9.3 \%$ (463 million patients), which is expected to increase to $10.2 \%$ by 2030 ( 578 million) and $10.9 \%$ by 2045 (700 million) [3]. Normally, insulin lowers blood glucose levels by stimulating peripheral glucose uptake and suppressing hepatic glucose production; however, a dysfunction could conduct to insulin resistance. Thus, an increase in insulin secretion or $\beta$-cell mass can compensate for the insulin resistance by normal $\beta$ cells, producing more circulating insulin; however, insufficient compensation results in the onset of glucose intolerance, leading to exacerbation of hyperglycaemia. Once exhausted, pancreatic $\beta$ cells can no longer overproduce insulin and DM develops $[2,4,5]$.

\section{Oxidative Stress in Diabetes Mellitus}

Prolonged hyperglycaemia and hyperlipidaemia in DM can lead to oxidative stress as the result of reactive oxygen species (ROS) overproduction in the cytosol or mitochondria, which counteracts the cellular redox balance and induces more oxidative stress [6-8]. Oxidative stress, therefore, causes significant damage to various cellular biomolecules, 
including proteins, lipids, and DNA $[9,10]$. The resulting dysregulated expression in numerous genes and proteins leads to impaired insulin secretion and signalling [11], which contributes to the development and progression of DM complications such as retinopathy, nephropathy, non-alcoholic fatty liver disease, hypertension, and cardiovascular diseases, jointly known as metabolic syndrome [12-15]. DM is also associated with a long list of risk factors, including gestational DM, sedentary lifestyle, genetics, and obesity $[5,16]$.

As pancreatic $\beta$-cell function gradually worsens, hyperglycaemia becomes apparent. Glucose toxicity in $\beta$ cells in DM is, therefore, a significant cause of oxidative stress $[9,17,18]$. Furthermore, the expression of antioxidant enzymes such as superoxide dismutase (SOD), catalase (CAT), and glutathione peroxidase (GPx) is low in pancreatic $\beta$ cells; consequently, $\beta$ cells could be a target of oxidative stress-mediated tissue damage [18-20]. High glucose exposure increases oxidative stress in human islets and pancreatic $\beta$-cell lines, and GPx overexpression increases GPx activity and protects islets against adverse effects [21]. Oxidative stress is therefore a feature that contributes to insulin resistance and $\beta$-cell dysfunction in DM. The diabetic brain can also be injured, showing a wide profile of microstructural and macrostructural changes, leading to neurovascular deterioration, progressive cognition dysfunction, excessive oxidative stress, and neurodegeneration [22].

\section{Animal Models of Diabetes Mellitus}

Due to their relatively similar physiology to humans and ease of handling and housing, mice and rats are widely used as pre-clinical animal models for studying metabolic disorders $[23,24]$. These rodents are therefore useful as models for investigating DM-related molecular and cellular events and can provide knowledge about the effects of anti-DM agents in individual or groups of tissues.

Streptozotocin (STZ) is an antibiotic that produces pancreatic islet $\beta$-cell destruction and is widely used experimentally to produce a DM1 model. Within $48 \mathrm{~h}$, a single high dose of STZ causes complete $\beta$-cell necrosis and DM [25]. However, low doses of STZ for 5 days elicit partial $\beta$-cell loss, which results in hypo-insulinaemia and hyperglycaemia $[26,27]$. There are data indicating a major role for oxidative stress as a consequence of STZ-induced DM in rats, which demonstrated increased oxidative stress in the early stages of STZinduced DM in rats as well as mitochondrial dysfunction [28]. In addition, STZ-induced DM in female rats on day 5 of pregnancy affected the intra-uterine developmental timeline, which resulted from maternal DM and preceded embryo implantation, restricted embryofoetal growth, and delayed the maturation and remodelling of the structures derived from neural crest cells [29]. The administration of STZ-nicotinamide (NA) in rats has been proposed to induce DM2, because STZ causes pancreatic $\beta$-cell damage, whereas NA in rats partially protects pancreatic $\beta$ cells against STZ [30].

Food highly enriched in fats, commonly known as high-fat diets (HFDs), either alone or in combination with sodium chloride or glucose is considered to mimic human DM2 [23]. There are data indicating the role of oxidative stress in HFDs, given that ROS production might be an initial event triggering HFD-induced insulin resistance [31]. To induce DM2 in a shorter period, HFD combined with low-dose STZ has been employed [32].

The C57BL/6 J mouse strain is extensively used as a model for diet-induced obesity (DIO) due to susceptibility to developing severe obesity, glucose intolerance, elevated adiposity, and moderate insulin resistance $[33,34]$. However, the DIO C57BL/6J model is not the perfect choice for studying the effects of diabetes because this model rarely develops hyperglycaemia or islet atrophy when fed an HFD [23,35].

Alloxan is an organic compound, urea derivative, carcinogen, and cytotoxic glucose analogue and is, therefore, one of the most commonly employed diabetogenic agents. Alloxan promotes selective pancreatic $\beta$-cell necrosis by promoting ROS accumulation [36,37].

Certain genetic rodent models have been extensively employed as pre-clinical models for DM, such as leptin-null $(o b / o b)$ mice and leptin receptor $(d b / d b)$ mutant mice [38,39]. $\mathrm{O} b / \mathrm{ob}$ mice maintained on a C57BL/6J genetic background exhibit early-onset severe obesity, reduced energy expenditure, hyperinsulinaemia, insulin resistance, and mild 
hyperglycaemia [40]. In contrast, the $o b / o b$ mice maintained on a C57BLKS/J background exhibit pronounced DM, severe hyperglycaemia, and pancreatic islet atrophy, leading to premature death [41]. Db/db mice are maintained on a C57BLKS/J genetic background, which imparts the phenotypic differences of severe diabetes [41]. There are data pointing to oxidative stress as a contributor to the patho-physiologic disorders observed in $o b / o b$ mice, wherein an increase in oxidative stress has been observed in $o b / o b$ mice as part of the DM-associated disorders [42,43]. Oxidative damage has been demonstrated in the brains of DM2 $d b / d b$ mice [44].

There is a sex difference in most rodent DM2 models, with the Zucker Diabetic Fatty (ZDF) rat providing one example. Female ZDF rats maintain normal insulin and glucose levels throughout their lives, despite developing obesity to a similar degree as the males. In contrast, male ZDF rats develop obesity, insulin resistance, severe hyperglycaemia, and hyperlipidaemia as a consequence of DM2 [45,46]. Therefore, the sexual dimorphism in blood glucose can be translated to human beings. The role of oxidative stress can also be a contributor to the pathophysiologic disorders observed in ZDF rats because increased ROS production and mitochondrial dysfunction has been shown in ZDF rat brains [47].

Otsuka Long-Evans Tokushima Fatty (OLETF) rats develop DM and lack the cholecystokinin receptor type A, a gut-derived peptide hormone that works as a peripheral satiation signal. Due to $\beta$-cell collapse, the characteristic symptoms are polydipsia and polyuria $[48,49]$. Evidence also points to the role of oxidative stress as a consequence of DM in OLETF rats because increased oxidative stress levels have been shown in the plasma, pancreas, and liver of OLETF rats as well as significantly decreased plasma SOD-like activity [50].

Goto-Kakizaki (GK) rats have neonatal $\beta$-cell mass deficiency, with $50 \%$ depletion in adult rats. Defects in $\beta$-cell metabolism and function are elicited, and a loss of $\beta$-cell mass occurs with chronic hyperglycaemia, oxidative stress, and inflammation. GK rats therefore constitute a non-obese polygenic DM2 model [51-53].

\section{Natural Compounds against Oxidative Stress in Animal Models of Diabetes Mellitus}

The use of natural compounds in animal DM models has been shown to improve glycaemic control, reduce inflammation, decrease oxidative stress and neurodegeneration, and prevent various complications of DM [54-57]. Table 1 summarises the outcomes for the protective effects of natural compounds against oxidative stress in animal DM models.

\subsection{Natural Polyphenols}

Natural polyphenols are secondary metabolites of plants and found largely in fruits; vegetables; cereals; and beverages such as wine, coffee, tea, and beer. Polyphenols are, therefore, considered the most abundant antioxidantantioxidants in the human diet, and diets rich in polyphenols provide protective effects against DM, cardiovascular diseases, cancer, and several neurodegenerative diseases. More than 8000 polyphenols have been identified in several plants and have been classified into various classes including phenolic acids, flavonoids, stilbenes, and lignans [58,59]. The effects of diverse natural polyphenols against oxidative stress have been demonstrated in various rodent DM models. Resveratrol is a natural polyphenol compound, widely found in grapes and blueberries. Long-term treatment with resveratrol improved neuronal injury and cognitive performance in STZinduced diabetic rats by attenuating inflammation, increasing malondialdehyde (MDA) levels (a marker of lipid peroxidation), and increasing SOD, CAT, and glutathione (GSH) levels in the hippocampus [60]. In STZ-induced diabetic rats, resveratrol treatment partially normalised oxidative biomarkers, such as the total oxidant status (TOS) and MDA levels, and improved CAT and SOD1 mRNA levels. Similarly, CAT, GPx, and glutathione S-transferase (GST) activity was also increased in the brains of treated diabetic rats [61]. The administration of resveratrol in STZ-NA-induced DM2 rats decreased blood glucose and glycated haemoglobin (HbA1c) levels and increased the antioxidant activity of SOD, CAT, GPx, and GSH in the liver. Resveratrol has also been shown to increase the expression 
of peroxisome proliferator-activated receptor-gamma (PPAR $\gamma)$ and fatty aldehyde dehydrogenase (FALDH) genes in adipose tissue. PPAR $\gamma$ is a transcription factor involved in adipogenesis, regulation of adipocyte gene expression, and glucose metabolism and acts as a key energy balance regulator. PPAR $\gamma$ activation also increases antioxidant defence and regulates mitochondrial function [62]. FALDH is an enzyme that can metabolise 4-hydroxynonenal (HNE) and decrease HNE-induced ROS production [63].

Table 1. The use of natural compounds as a strategy for counteracting oxidative stress in animal DM models.

\begin{tabular}{|c|c|c|c|c|}
\hline Compound & Model & \multicolumn{2}{|c|}{ Outcome } & \multirow[t]{2}{*}{ Reference } \\
\hline Polyphenols & & Oxidative Markers and Protection & Antioxidant Proteins & \\
\hline Resveratrol & $\begin{array}{l}\text { STZ-induced DM rats and } \\
\text { STZ-NA-induced DM rats }\end{array}$ & $\begin{array}{c}\text { Improved neuronal injury and cognitive } \\
\text { performance by attenuating inflammation, } \\
\downarrow \text { MDA levels. } \\
\downarrow \text { TOS and MDA levels. } \\
\downarrow \text { blood glucose and HbA1c levels and } \uparrow \\
\text { PPAR } \gamma \text { and FALDH genes. }\end{array}$ & $\begin{array}{c}\uparrow \text { SOD, CAT, and GSH levels in the } \\
\text { hippocampus. } \\
\text { Improved SOD1 and CAT mRNA } \\
\text { levels, } \uparrow \text { CAT, GPx, and GST } \\
\text { activity in the brain. } \\
\uparrow \text { SOD, CAT, GPx, and GSH } \\
\text { activity in the liver }\end{array}$ & {$[60,61,63]$} \\
\hline Curcumin & STZ-induced DM rats & $\begin{array}{c}\downarrow \text { blood glucose, } \uparrow \text { neuroprotection. } \\
\downarrow \text { TBARS levels, } \uparrow \text { AGE, AGE-R1 receptor, } \\
\text { glyoxalase- } 1 \text { in the kidneys and liver and } \\
\text { prevented dyslipidaemia. }\end{array}$ & $\begin{array}{c}\uparrow \mathrm{SOD}, \mathrm{CAT}, \mathrm{GPx} \text {, and GSH } \\
\text { activity in the hippocampus. } \\
\uparrow \mathrm{SOD}, \mathrm{CAT} \text {, and PON1 activity. }\end{array}$ & {$[64,65]$} \\
\hline Syringic acid & STZ-induced DM rats & $\begin{array}{l}\downarrow \text { blood glucose, improved memory, } \\
\text { learning and movement deficiency, } \downarrow \text { MDA } \\
\text { levels in the brain, sciatic nerve and spinal } \\
\text { cord, } \uparrow \text { mRNA expression of PGC } 1 \alpha \text { and } \\
\text { NRF1 in the brain. }\end{array}$ & & [66] \\
\hline \multicolumn{5}{|l|}{ Flavonoids } \\
\hline Quercetin & $\begin{array}{l}\text { STZ-induced DM rats, } \\
\text { STZ-NA-induced DM2 rats, } \\
\text { HFD/STZ-induced DM2 rats, } \\
\text { and } d b / d b \text { DM2 mice }\end{array}$ & $\begin{array}{c}\downarrow \text { blood glucose, } \downarrow \text { plasma TBARS, and } \\
\text { hydroperoxides. } \\
\downarrow \text { MDA levels in erythrocytes, } \downarrow \text { serum } \\
\text { NO levels. } \\
\downarrow \text { MDA levels. } \\
\downarrow \text { AOPP and MDA levels. } \\
\downarrow \text { ER-stress and MDA levels. } \\
\text { Ameliorated neurodegeneration, improved } \\
\text { learning and memory impairment, } \downarrow \\
\text { MDA levels. } \\
\downarrow \text { MDA levels, } \uparrow \text { ATP generation and } \\
\text { improved changes in mitochondria, } \uparrow \\
\text { AMPK, SIRT1, PGC1 } \alpha, \text { TFAM, and NRF1 } \\
\text { in plasma and sciatic nerves. }\end{array}$ & $\begin{array}{c}\uparrow \mathrm{SOD} \text { and CAT activity, } \uparrow \text { vitamin } \\
\mathrm{C} \text { and E levels in erythrocytes } \\
\text { and plasma. } \\
\uparrow \mathrm{SOD}, \mathrm{CAT} \text {, and GPx levels in } \\
\text { pancreatic tissue. } \\
\uparrow \mathrm{SOD}, \mathrm{CAT} \text {, and GPx activity and } \\
\uparrow \mathrm{SOD} 1, \mathrm{CAT} \text {, and GPx1 protein } \\
\text { levels in the heart. } \\
\uparrow \mathrm{GSH} \text { levels in pancreatic tissue. } \\
\uparrow \mathrm{SOD}, \mathrm{CAT} \text {, and GPx activities in } \\
\text { the pancreas. } \\
\uparrow \mathrm{SOD}, \mathrm{CAT} \text {, and GPx activity in } \\
\text { the brain. }\end{array}$ & {$[67-73]$} \\
\hline Kaempferol & $\begin{array}{l}\text { STZ-induced DM rats and } \\
\text { STZ-induced DM mice }\end{array}$ & $\begin{array}{c}\downarrow \text { blood glucose, } \downarrow \text { TBARS, } \\
\quad \text { and hydroperoxides. } \\
\downarrow \text { DHE level and 3-nitrotyrosine, } \uparrow \text { Nrf-2, } \\
\text { and NQO1 expression levels. }\end{array}$ & $\begin{array}{c}\uparrow \text { SOD, CAT, GPx, and GST } \\
\text { activity, } \uparrow \text { GSH, vitamin C, and } \\
\text { vitamin E in the plasma, heart, } \\
\text { liver, and kidneys. }\end{array}$ & {$[74,75]$} \\
\hline Luteolin & STZ-induced DM rats & $\begin{array}{l}\text { Improved neuronal injury and cognitive } \\
\text { performance, } \downarrow \text { MDA levels. }\end{array}$ & $\begin{array}{c}\uparrow \mathrm{SOD}, \mathrm{CAT} \text {, and GSH activity in } \\
\text { the cerebral cortex and } \\
\text { hippocampus. }\end{array}$ & [76] \\
\hline $\begin{array}{l}\text { Ficus } \\
\text { deltoidea }\end{array}$ & $\begin{array}{l}\text { STZ-induced DM rats and } \\
\text { STZ-NA-induced DM2 rats }\end{array}$ & $\begin{array}{c}\text { Improved spatial learning and memory, } \downarrow \\
\text { TBARS in the brain. } \\
\downarrow \text { blood glucose and } \downarrow \text { MDA levels in the } \\
\text { pancreas and liver. }\end{array}$ & $\begin{array}{l}\uparrow \text { SOD and GPx activity in } \\
\text { the brain. } \\
\uparrow \text { SOD, CAT, GPx, and GSH levels } \\
\text { in the pancreas and liver. }\end{array}$ & {$[77,78]$} \\
\hline Chrysin & $\begin{array}{l}\text { STZ-induced DM rats and } \\
\text { HFD/sucrose-induced } \\
\text { DM2 rats }\end{array}$ & $\begin{array}{l}\downarrow \text { blood glucose, improved learning, and } \\
\text { memory, } \downarrow \text { MDA levels in the brain. } \\
\downarrow \text { blood glucose and lipids and } \uparrow \text { insulin, } \downarrow \\
\text { MDA levels, } \downarrow \text { OH and } \mathrm{H}_{2} \mathrm{O}_{2} \text { in the } \\
\text { gastrocnemius muscle. }\end{array}$ & $\begin{array}{l}\uparrow \mathrm{SOD}, \mathrm{CAT} \text {, and GSH activity in } \\
\text { the cerebral cortex and } \\
\text { hippocampus. }\end{array}$ & {$[79,80]$} \\
\hline \multicolumn{5}{|l|}{ Propolis } \\
\hline Chinese & $\begin{array}{l}\text { Alloxan-induced DM rats and } \\
\text { STZ-induced DM rats }\end{array}$ & $\begin{array}{c}\downarrow \text { blood glucose, } \downarrow \text { MDA, NO, and NOS. } \\
\downarrow \text { blood glucose, } \downarrow \text { HbA1c, } \downarrow \text { MDA, } \downarrow \text { ROS } \\
\text { and RNS in serum. }\end{array}$ & $\uparrow$ SOD levels in blood. & {$[81,82]$} \\
\hline
\end{tabular}


Table 1. Cont.

\begin{tabular}{|c|c|c|c|c|}
\hline \multirow{2}{*}{$\begin{array}{c}\text { Compound } \\
\text { Polyphenols }\end{array}$} & \multirow[t]{2}{*}{ Model } & \multicolumn{2}{|c|}{ Outcome } & \multirow[t]{2}{*}{ Reference } \\
\hline & & Oxidative Markers and Protection & Antioxidant Proteins & \\
\hline $\begin{array}{l}\text { Chinese and } \\
\text { Brazilian }\end{array}$ & STZ-induced DM rats & $\begin{array}{l}\downarrow \text { blood glucose, } \downarrow \text { MDA levels in blood } \\
\text { and kidneys. }\end{array}$ & $\begin{array}{l}\uparrow \mathrm{SOD} \text { in blood, } \uparrow \mathrm{CAT} \text { in kidneys, } \\
\text { and } \uparrow \text { GPx in the liver. }\end{array}$ & [83] \\
\hline Croatian & Alloxan-induced DM mice & $\begin{array}{l}\downarrow \text { MDA levels in liver and } \uparrow \text { antiradical } \\
\text { activity and } \downarrow \beta \text {-carotene degradation. }\end{array}$ & & [84] \\
\hline Malaysian & STZ-induced DM rats & $\begin{array}{c}\downarrow \text { blood glucose, } \uparrow \mathrm{TAC} \text { and } \downarrow \text { MDA in } \\
\text { the pancreas. }\end{array}$ & $\begin{array}{l}\uparrow \text { SOD, CAT, GPx, GR, and } \\
\text { GST activities. }\end{array}$ & [85] \\
\hline Taiwanese & HFD/STZ-induced DM2 rats & $\downarrow$ blood glucose and $\downarrow$ TBARS in serum. & $\uparrow \mathrm{SOD}$ and GPx activities. & [86] \\
\hline Mexican & STZ-induced DM mice & $\begin{array}{c}\downarrow \text { blood glucose and } \uparrow \text { plasma } \\
\text { insulin levels. }\end{array}$ & $\begin{array}{l}\uparrow \mathrm{SOD}, \mathrm{CAT} \text {, and GPx activities in } \\
\text { the pancreas. }\end{array}$ & [87] \\
\hline CAPE & STZ-induced DM rats & $\begin{array}{c}\uparrow \text { HO- } 1 \text { and GGCL, } \downarrow \text { nitrite } / \text { nitrate levels, } \\
\text { and } \downarrow \text { protein expression of iNOS in } \\
\text { the pancreas. }\end{array}$ & & [88] \\
\hline \multicolumn{5}{|l|}{ Alkaloids } \\
\hline Berberine & $\begin{array}{c}\text { HFD/STZ-induced DM2 rats, } \\
\text { STZ-NA-induced DM2 mice, } \\
\text { and HFD/glucose-induced } \\
\text { DM2 hamsters }\end{array}$ & $\begin{array}{c}\downarrow \text { MDA levels. } \\
\downarrow \text { blood glucose, and } \downarrow \text { MDA levels in the } \\
\text { liver and brain. } \\
\downarrow \text { MDA plasma levels, } \downarrow \text { TBARS, and } \\
\downarrow \text { blood glucose, improved memory } \\
\text { impairment, axonopathy, and tau } \\
\text { hyperphosphorylation. }\end{array}$ & $\begin{array}{c}\uparrow \text { SOD, CAT, GPx, and GSH } \\
\text { activity in the liver and serum. } \\
\uparrow \text { SOD1 mRNA in liver, } \uparrow \text { SOD and } \\
\text { CAT activities in the kidneys. } \\
\uparrow \text { SOD activity in plasma. }\end{array}$ & [89-92] \\
\hline Vindoline & $\begin{array}{l}\text { STZ/fructose-induced } \\
\text { DM2 rats }\end{array}$ & $\begin{array}{c}\downarrow \text { blood glucose and } \uparrow \text { ORAC. } \\
\uparrow \text { FRAP in the cardiac tissue, } \uparrow \text { ORAC, } \downarrow \\
\text { MDA levels in the kidneys. }\end{array}$ & $\begin{array}{l}\uparrow \text { SOD activity in the liver. } \\
\uparrow \text { SOD activity. }\end{array}$ & {$[93,94]$} \\
\hline Oxymatrine & HFD/STZ-induced DM2 rats & $\downarrow$ blood glucose and $\downarrow$ MDA levels. & $\begin{array}{l}\uparrow \text { SOD, CAT, and GPx activity in } \\
\text { the kidneys. }\end{array}$ & [95] \\
\hline \multicolumn{5}{|l|}{ Ginseng } \\
\hline Ginsenosides & GK DM2 rats & $\begin{array}{l}\downarrow \text { blood glucose, improved learning, and } \\
\text { memory decline, } \downarrow \text { MDA levels. }\end{array}$ & $\begin{array}{l}\uparrow \text { SOD activity in the } \\
\text { hippocampus. }\end{array}$ & [96] \\
\hline Korean red & OLETF DM rats & $\downarrow$ blood glucose and $\downarrow$ MDA levels. & $\uparrow$ GPx activity in plasma. & [97] \\
\hline
\end{tabular}

Curcumin is a polyphenolic compound that has been shown to have anti-hyperglycaemic, anti-inflammatory, and antioxidant activity, attenuating DM complications [98]. Treatment with curcumin had a neuroprotective effect in the hippocampus of STZ-induced diabetic rats and significantly increased the activity of SOD, CAT, GPx, and GSH [64]. In addition, curcumin treatment of STZ-induced diabetic rats decreased the plasma levels of the oxidative biomarker thiobarbituric acid reactive substances (TBARS); increased the activity of the antioxidant enzymes SOD, CAT, and paraoxonase-1 (PON1) in the kidneys and liver; and increased the levels of advanced glycation end product (AGE) and detoxification system components (AGE-R1 receptor and glyoxalase-1). Additionally, the combination of curcumin and aminoguanidine, a therapeutic agent with anti-AGE activity, prevented dyslipidaemia in diabetic rats [65]. The neuroprotective effects of syringic acid, a natural polyphenolic derivative of benzoic acid, were evaluated in STZ-induced diabetic rats. Treatment with a syringic acid significantly improved the rats' memory; improved their learning and movement deficiency; reduced MDA levels in the brain, sciatic nerve, and spinal cord, and upregulated the brain mRNA expression of PPAR $\gamma$ coactivator 1 alpha $(\mathrm{PGC1} 1 \alpha)$ and nuclear respiratory factor (NRF1) [66]. PGC1 $\alpha$ is a transcription coactivator that regulates mitochondrial biogenesis and induces NRF1 transcription [99]

\subsection{Flavonoids}

Flavonoids belong to a large group of natural polyphenolic phytochemicals with several subclasses and have shown beneficial effects, such as antioxidantantioxidant activity in several neurodegenerative and neuropsychiatric disorders, as well as anti-inflammatory, anti-obesity, anti-diabetic, and cardioprotective activity. Quercetin is a flavonoid com- 
pound present in a wide variety of fruits and vegetables and has been shown to exert therapeutic effects [100]. The oral administration of quercetin to STZ-induced diabetic rats resulted in a decrease in blood glucose, plasma TBARS, and hydroperoxides levels. Quercetin also increased SOD and CAT activity and vitamin C and E levels to near normal values in the erythrocytes and plasma of treated rats [67]. Furthermore, quercetin treatment decreased MDA levels in erythrocytes and serum nitric oxide (NO) and increased SOD, CAT, and GPx levels in the pancreatic tissue of STZ-treated rats [68]. Quercetin treatment of STZ-NA-induced DM2 rats decreased MDA levels and increased SOD, CAT, and GPx activity levels and caused a significant increase in SOD1, CAT, and GPx1 protein levels in the heart tissue homogenates of treated rats [69]. Similarly, the administration of quercetin resulted in a significant decrease in advanced oxidation protein products (AOPP) and MDA levels along with a significant increase in GSH levels in pancreatic tissue homogenates of HFD/STZ-induced DM2 rats [70]. Similarly, quercetin treatment reduced ER stress-mediated oxidative stress, reduced MDA levels, and improved SOD, CAT, and GPx activity in the pancreas of STZ-induced diabetic rats [71]. Moreover, quercetin ameliorated neurodegeneration; improved learning and memory impairment; reduced MDA levels; and increased SOD, CAT, and GPx activity in the brain of $\mathrm{db} / \mathrm{db}$ mice, which is an animal model of DM2 [72]. Lastly, quercetin decreased MDA levels, increased ATP generation, and corrected morphological changes in mitochondria in the plasma and sciatic nerves of STZ-induced diabetic rats. Quercetin treatment also promoted the expression of phosphorylated adenosine $5^{\prime}$-monophosphate-activated protein kinase (AMPK), sirtuin 1 (SIRT1) a sensor of energetic metabolism, PGC1 $\alpha$, TFAM, and NRF1 (key regulators of mitochondrial biogenesis, energy metabolism, and oxidative phosphorylation) [73]. Kaempferol is a flavonoid that naturally occurs in a variety of vegetables, fruits, tea, and wine and exhibits a wide range of kinds of pharmacological activity, including antioxidant, anti-inflammatory, neuroprotective, and anti-diabetic activity [101]. The ameliorative effects of kaempferol have been observed in STZ-induced diabetic rats, with a significant decline in TBARS and lipid hydroperoxide towards normal levels; increased activity of SOD, CAT, GPx, and GST; and increased levels of non-enzymatic antioxidants towards normal levels, such as GSH, vitamin C, and vitamin E in the plasma, heart, liver, and kidneys of treated rats [74]. Kaempferol in the heart tissue of STZ-induced diabetic mice decreased the generation of oxidative stress measured with dihydroethidium (DHE), reduced the generation of 3-nitrotyrosine (a product of peroxynitrite), increased the expression of the nuclear factor erythroid 2-related factor 2 (Nrf-2) signalling pathway, which plays a major role in regulating of oxidative stress and increased NQO1 expression. In vitro, kaempferol decreased the levels of MDA and DHE and enhanced SOD activity in H9c2 cells treated with high quantities of glucose [75].

Luteolin is a flavonoid with antioxidant and neuroprotective activity. Long-term treatment with luteolin improved neuronal injury and cognitive performance in STZinduced diabetic rats; significantly inhibited the increase in MDA levels; and improved SOD, CAT, and GSH activity in the cerebral cortex and hippocampus [76]. The leaves of Ficus deltoidea have been extensively used as herbal medicine to normalise blood sugar levels and contain more than 20 varieties of flavonoids, giving the leaves antioxidant effects [102]. Treatment with Ficus deltoidea in STZ-induced diabetic rats improved spatial learning and memory, increased SOD and GPx activity, and significantly reduced TBARS in the brains of diabetic rats [77]. Ficus deltoidea also significantly increased SOD, CAT, GPx, and GSH levels and reduced MDA levels in the pancreas and livers of STZ-NAinduced DM2 rats [78]. Long-term treatment with the flavonoid chrysin suppressed the increase in MDA content in the brains of STZ-induced diabetic rats; increased the activity of SOD, CAT, and GSH in the cerebral cortex and hippocampus; and improved learning and memory function [79]. Treatment with chrysin normalised the altered blood glucose levels, serum insulin levels, and lipid profile and significantly reduced the levels of MDA, hydroxyl radical $(\mathrm{OH})$, and hydrogen peroxide $\left(\mathrm{H}_{2} \mathrm{O}_{2}\right)$ in the gastrocnemius muscle of HFD/sucrose-induced DM2 rats [80]. 


\subsection{Propolis}

Propolis is a complex resinous material that consists of sap, bark, and bee excreta accumulated in beehives. More than 300 compounds including flavonoids, phenolic acids, volatile organic compounds, phenolic aldehydes, alcohols, ketones, sesquiterpenes, quinones, coumarins, steroids, and amino acids have been isolated from propolis [103]. The effects of propolis against oxidative stress have been demonstrated in diverse rodent DM models. Extracts of propolis from north China have significantly decreased levels of blood glucose, MDA, NO, and nitric oxide (NOS) synthetase, whereas blood SOD levels were increased in alloxan-induced rats [81]. In STZ-induced diabetic rats, Chinese and Brazilian propolis significantly inhibited body weight loss and blood glucose increases; decreased MDA levels in the blood and kidneys; and slightly increased SOD in the blood, CAT in the kidneys, and GPx in the liver [83]. Treatment with Croatian propolis preparations prevented bodyweight reduction in alloxan-induced diabetic mice and significantly decreased MDA concentrations in the liver. Moreover, 2,2-diphenyl-1-picrylhydrazyl (DPPH) is frequently used to determine radical-scavenging activity, and propolis preparations have demonstrated anti-radical activity. The antioxidant capacity of propolis preparations has been evaluated using a $\beta$-carotene-linoleic acid assay, showing that they inhibited $\beta$-carotene degradation [84]. Malaysian propolis increased the activity of SOD, CAT, GPx, glutathione reductase (GR), and GST; total antioxidant capacity (TAC) and MDA level was significantly decreased in the pancreas of STZ-induced diabetic rats [85]. Taiwanese green propolis increased SOD and GPx activity and produced a decrease in a TBARS assay in the serum of HFD/STZ-induced DM2 rats [86]. Similarly, Mexican propolis significantly inhibited increases in blood glucose and loss of body weight in STZ-induced mice, increased plasma insulin levels, and increased the activity of SOD, CAT, and GPx enzymes in the pancreas. The chemical composition analysis showed that Mexican propolis was rich in flavonoids such as kaempferol, quercetin naringin, pinocembrin, naringenin, acacetin, chrysin, and luteolin [87]. Moreover, extract of Chinese propolis decreased the levels of $\mathrm{HbA1c}$, which also resulted in the decrease of MDA, ROS, and reactive nitrogen species (RNS) in the serum of STZ-induced diabetic rats [82]. The protective effects of caffeic acid phenethyl ester (CAPE), a natural phenolic compound derived from honeybee hive propolis, were demonstrated in STZ-induced diabetic rats. The expression levels of antioxidant enzyme-related proteins, such as heme oxygenase-1 (HO-1) and gammaglutamylcysteine ligase (GGCL), were restored. Nrf-2 modulates the expression of genes such as HO-1 and GGCL. CAPE also decreased the nitrite/nitrate levels and decreased the protein expression of iNOS in the pancreas of STZ-induced diabetic rats [88]. Figure 1 summarises the protective effects of various natural compounds in animal DM models.

Natural Compounds

Polyphenols, Flavonoids, Propolis, Alkaloids and Ginseng

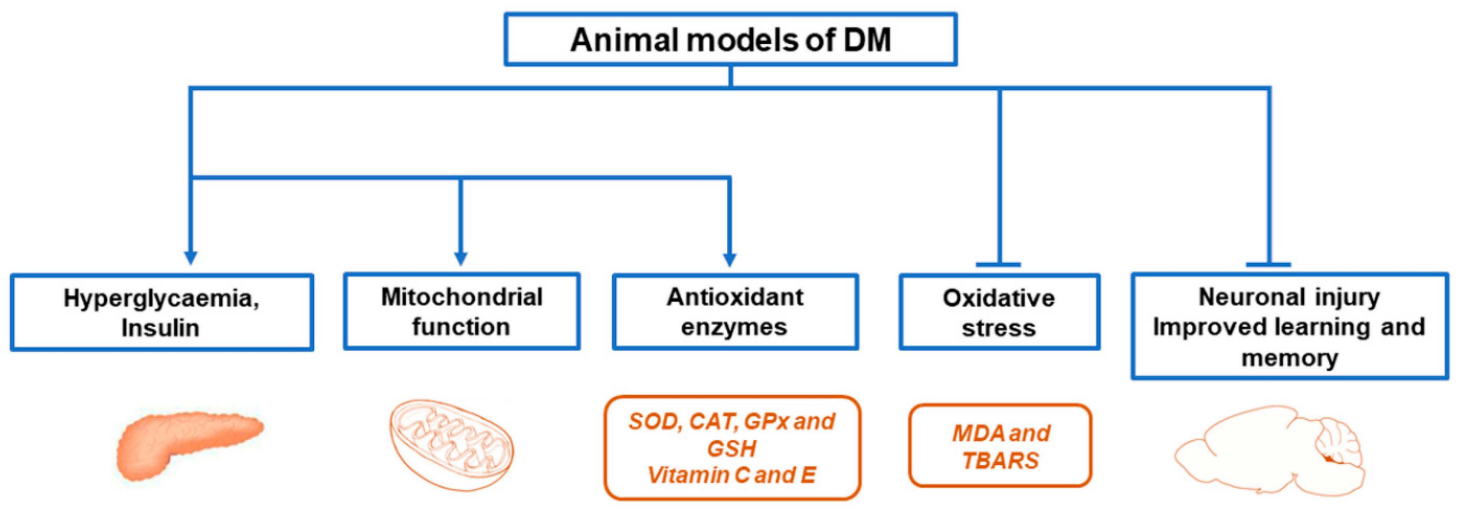

Figure 1. Protective effects of various natural compounds in animal DM models. Natural compounds prevented hyperglycaemia, ROS production, and neuronal injury; increased insulin secretion and antioxidant enzymes; and improved mitochondrial function, learning, memory, and lipid metabolism, among others. 


\subsection{Alkaloids}

Alkaloids are a class of natural compounds derived from natural sources, such as plants. There are approximately 20,000 known alkaloids, most of which have been isolated from plants. However, alkaloids have also been found in algae; marine organisms; and animals such as insects, toads, and salamanders [104]. Berberine, an isoquinoline alkaloid derived from the ancient Chinese herb Coptis Chinensis French, has been used to treat DM for thousands of years, with a broad range of effects, such as decreased oxidative stress, reduced inflammation, and protection against neurodegenerative diseases [105]. Berberine decreased MDA levels and increased SOD, CAT, GPx, and GSH activity in the livers and sera of HFD/STZ-induced DM2 rats [89]. Berberine also increased hepatic SOD1 mRNA expression and kidney SOD and CAT activity to normal levels and decreased MDA levels in the livers and brains of STZ-NA-induced DM2 mice [90]. In hamsters fed a high content of glucose and HFD, treatment with berberine reduced the plasma levels of MDA and TBARS and increased plasma SOD activity [91]. Berberine significantly attenuated memory impairment, axonopathy, and tau hyperphosphorylation in HFD/STZinduced DM2 rats. Primary neurons treated simultaneously with high quantities of glucose and berberine improved axonal transport, decreased MDA levels, and increased SOD activity [92]. Vindoline, an indole alkaloid present in the leaves of the Catharanthus roseus plant, might serve as an insulin sensitiser. The administration of vindoline significantly improved oxygen radical absorbance capacity (ORAC), an assay measuring the ability of antioxidants in a particular sample to scavenge radicals, and improved SOD activity in the livers of rats exposed to $10 \%$ fructose with STZ employed as a DM2 model [94]. Using the above rat DM2 model, treatment with vindoline improved the ferric-reducing antioxidant power (FRAP) in cardiac tissue significantly improved the ORAC and SOD activity and significantly reduced MDA levels in the kidneys [93]. Oxymatrine, a major quinolizidine alkaloid in Sophora flavescens, exhibits several pharmacological effects, such as anti-inflammatory, anti-oxidative, and neuroprotective activity. Treatment with oxymatrine effectively increased the activity of SOD, CAT, and GPx and decreased MDA content in the kidneys of HFD/STZ-induced DM2 rats [95].

\subsection{Ginseng}

Ginseng is a traditional Chinese herb containing active ingredients known as ginsenosides, the main compounds that elicit the therapeutic actions of ginseng. Ginsenoside treatment significantly decreased MDA activity and increased SOD activity in the hippocampus and improved learning and memory decline in the GK DM2 rat model [96]. Korean red ginseng has antioxidant and cardio-protective effects, and therefore, treatment with this herb decreased MDA levels and increased GPx activity in the plasma of DM2 OLETF rats [97].

\section{Clinical Trials}

Regardless of the great attributes and potentials of natural compounds used for the management or treatment of DM in rodent models, there is limited information concerning their efficacy in human clinical trials. Hence, only a few natural compounds have been explored in human clinical trials. Some natural components that have been studied in clinical trials are as follows. The antidiabetic activity of ginseng has been demonstrated in clinical trials [106]. Grape polyphenols prevented oxidative stress and insulin resistance in first-degree relatives of DM2 patients [107]. A moderate antidiabetic effect of cinnamon was observed in a randomised placebo-controlled clinical trial [108]. Allium cepa L., also known as the bulb onion or common onion, has been shown to exhibit antidiabetic activity [109]. Aloe vera extracts have been shown to exhibit a substantial decrease in glucose [110]. Finally, it has been shown that some natural compounds could improve DM in clinical trials. However, more clinical trials and prospective, well-designed research are still needed to confirm these results. 


\section{Conclusions}

As a chronic metabolic disease with several causative factors, DM is characterised by insulin deficiency and insulin resistance. In DM2, hyperglycaemia and hyperlipidaemia generate oxidative stress, causing cellular metabolic dysregulation. We focused on DM rodent models that play an important role in presenting the pathogenesis of human DM and its complications. Accordingly, diabetic rodent models are essential for studying several complications of DM, such as oxidative stress, and for developing new therapeutic strategies and novel drugs. The use of natural compounds for the management and treatment of DM is increasing, because the available medications sold over the counter are very expensive and have several side effects. The study of natural compounds with anti-diabetic potential is gaining greater attention daily because these compounds possess the ability to mitigate DM via several mechanisms such as the regulation of hyperglycaemia, decrease of oxidative stress, and neuronal injury; increased insulin secretion and antioxidant enzymes; and improved mitochondrial function, learning, memory, and lipid metabolism in rodent models. Thus, natural compounds could contribute to expanding the therapeutic options for treating or reducing the complications associated with DM. Nevertheless, only a few natural compounds have been used in clinical studies. Hence, there is a need for further research progress in the area of natural compounds with anti-diabetes activity and characterised as potential compounds employed as clinical medication or dietary supplements to ameliorate the management or treatment of DM.

Author Contributions: M.S.-G. and J.C.C. both conceived the topic of the review article and wrote a manuscript draft. J.C.C. finalised the manuscript. All authors have read and agreed to the published version of the manuscript.

Funding: This research was funded by Fondos Federales, grant number HIM-2017-032 and HIM2018-046.

Institutional Review Board Statement: Not applicable.

Informed Consent Statement: Not applicable.

Data Availability Statement: Not applicable.

Acknowledgments: This work was supported by Fondos Federales HIM-2017-032 and HIM-2018-046.

Conflicts of Interest: The authors declare no conflict of interest.

\section{References}

1. Scheen, A.J. Pathophysiology of type 2 diabetes. Acta Clin. Belg. 2003, 58, 335-341. [CrossRef] [PubMed]

2. Skyler, J.S.; Bakris, G.L.; Bonifacio, E.; Darsow, T.; Eckel, R.H.; Groop, L.; Groop, P.H.; Handelsman, Y.; Insel, R.A.; Mathieu, C.; et al. Differentiation of Diabetes by Pathophysiology, Natural History, and Prognosis. Diabetes 2017, 66, 241-255. [CrossRef] [PubMed]

3. Saeedi, P.; Petersohn, I.; Salpea, P.; Malanda, B.; Karuranga, S.; Unwin, N.; Colagiuri, S.; Guariguata, L.; Motala, A.A.; Ogurtsova, K.; et al. Global and regional diabetes prevalence estimates for 2019 and projections for 2030 and 2045: Results from the International Diabetes Federation Diabetes Atlas, 9(th) edition. Diabetes Res. Clin. Pract. 2019, 157, 107843. [CrossRef]

4. Robertson, R.P. Oxidative stress and impaired insulin secretion in type 2 diabetes. Curr. Opin. Pharmacol. 2006, 6, 615-619. [CrossRef] [PubMed]

5. Martin-Timon, I.; Sevillano-Collantes, C.; Segura-Galindo, A.; Del Canizo-Gomez, F.J. Type 2 diabetes and cardiovascular disease: Have all risk factors the same strength? World J. Diabetes 2014, 5, 444-470. [CrossRef]

6. Nishikawa, T.; Araki, E. Impact of mitochondrial ROS production in the pathogenesis of diabetes mellitus and its complications. Antioxid. Redox. Signal 2007, 9, 343-353. [CrossRef] [PubMed]

7. Volpe, C.M.O.; Villar-Delfino, P.H.; Dos Anjos, P.M.F.; Nogueira-Machado, J.A. Cellular death, reactive oxygen species (ROS) and diabetic complications. Cell Death Dis. 2018, 9, 119. [CrossRef] [PubMed]

8. Gerber, P.A.; Rutter, G.A. The Role of Oxidative Stress and Hypoxia in Pancreatic Beta-Cell Dysfunction in Diabetes Mellitus. Antioxid. Redox. Signal 2017, 26, 501-518. [CrossRef]

9. Zhang, P.; Li, T.; Wu, X.; Nice, E.C.; Huang, C.; Zhang, Y. Oxidative stress and diabetes: Antioxidative strategies. Front. Med. 2020, 14, 583-600. [CrossRef]

10. Corona, J.C.; Duchen, M.R. Impaired mitochondrial homeostasis and neurodegeneration: Towards new therapeutic targets? J. Bioenerg. Biomembr. 2015, 47, 89-99. [CrossRef] [PubMed] 
11. Houstis, N.; Rosen, E.D.; Lander, E.S. Reactive oxygen species have a causal role in multiple forms of insulin resistance. Nature 2006, 440, 944-948. [CrossRef] [PubMed]

12. Gallagher, E.J.; Leroith, D.; Karnieli, E. Insulin resistance in obesity as the underlying cause for the metabolic syndrome. Mt. Sinai J. Med. 2010, 77, 511-523. [CrossRef] [PubMed]

13. Wu, M.Y.; Yiang, G.T.; Lai, T.T.; Li, C.J. The Oxidative Stress and Mitochondrial Dysfunction during the Pathogenesis of Diabetic Retinopathy. Oxid. Med. Cell Longev. 2018, 2018, 3420187. [CrossRef]

14. Spahis, S.; Borys, J.M.; Levy, E. Metabolic Syndrome as a Multifaceted Risk Factor for Oxidative Stress. Antioxid. Redox. Signal 2017, 26, 445-461. [CrossRef] [PubMed]

15. Ritchie, R.H. Evidence for a causal role of oxidative stress in the myocardial complications of insulin resistance. Heart Lung Circ. 2009, 18, 11-18. [CrossRef] [PubMed]

16. Wu, Y.; Ding, Y.; Tanaka, Y.; Zhang, W. Risk factors contributing to type 2 diabetes and recent advances in the treatment and prevention. Int. J. Med. Sci. 2014, 11, 1185-1200. [CrossRef] [PubMed]

17. Robertson, R.P.; Harmon, J.; Tran, P.O.; Poitout, V. Beta-cell glucose toxicity, lipotoxicity, and chronic oxidative stress in type 2 diabetes. Diabetes 2004, 53 (Suppl. 1), S119-S124. [CrossRef]

18. Drews, G.; Krippeit-Drews, P.; Dufer, M. Oxidative stress and beta-cell dysfunction. Pflugers Arch. 2010, 460, 703-718. [CrossRef] [PubMed]

19. Lenzen, S.; Drinkgern, J.; Tiedge, M. Low antioxidant enzyme gene expression in pancreatic islets compared with various other mouse tissues. Free Radic. Biol. Med. 1996, 20, 463-466. [CrossRef]

20. Tiedge, M.; Lortz, S.; Drinkgern, J.; Lenzen, S. Relation between antioxidant enzyme gene expression and antioxidative defense status of insulin-producing cells. Diabetes 1997, 46, 1733-1742. [CrossRef] [PubMed]

21. Tanaka, Y.; Tran, P.O.; Harmon, J.; Robertson, R.P. A role for glutathione peroxidase in protecting pancreatic beta cells against oxidative stress in a model of glucose toxicity. Proc. Natl. Acad. Sci. USA 2002, 99, 12363-12368. [CrossRef]

22. Hamed, S.A. Brain injury with diabetes mellitus: Evidence, mechanisms and treatment implications. Expert Rev. Clin. Pharmacol. 2017, 10, 409-428. [CrossRef] [PubMed]

23. Kleinert, M.; Clemmensen, C.; Hofmann, S.M.; Moore, M.C.; Renner, S.; Woods, S.C.; Huypens, P.; Beckers, J.; de Angelis, M.H.; Schurmann, A.; et al. Animal models of obesity and diabetes mellitus. Nat. Rev. Endocrinol. 2018, 14, 140-162. [CrossRef] [PubMed]

24. Rees, D.A.; Alcolado, J.C. Animal models of diabetes mellitus. Diabetes Med. 2005, 22, 359-370. [CrossRef] [PubMed]

25. Kolb, H. Mouse models of insulin dependent diabetes: Low-dose streptozocin-induced diabetes and nonobese diabetic (NOD) mice. Diabetes Metab. Rev. 1987, 3, 751-778. [CrossRef]

26. Like, A.A.; Rossini, A.A. Streptozotocin-induced pancreatic insulitis: New model of diabetes mellitus. Science 1976, 193, 415-417. [CrossRef] [PubMed]

27. Furman, B.L. Streptozotocin-Induced Diabetic Models in Mice and Rats. Curr. Protoc. Pharmacol. 2015, 70, 5.47.41-45.47.20. [CrossRef]

28. Raza, H.; Prabu, S.K.; John, A.; Avadhani, N.G. Impaired mitochondrial respiratory functions and oxidative stress in streptozotocin-induced diabetic rats. Int. J. Mol. Sci. 2011, 12, 3133-3147. [CrossRef] [PubMed]

29. Salazar Garcia, M.; Reyes Maldonado, E.; Revilla Monsalve, M.C.; Villavicencio Guzman, L.; Reyes Lopez, A.; Sanchez-Gomez, C. Importance of maternal diabetes on the chronological deregulation of the intrauterine development: An experimental study in rat. J. Diabetes Res. 2015, 2015, 354265. [CrossRef]

30. Masiello, P.; Broca, C.; Gross, R.; Roye, M.; Manteghetti, M.; Hillaire-Buys, D.; Novelli, M.; Ribes, G. Experimental NIDDM: Development of a new model in adult rats administered streptozotocin and nicotinamide. Diabetes 1998, 47, 224-229. [CrossRef]

31. Matsuzawa-Nagata, N.; Takamura, T.; Ando, H.; Nakamura, S.; Kurita, S.; Misu, H.; Ota, T.; Yokoyama, M.; Honda, M.; Miyamoto, K.; et al. Increased oxidative stress precedes the onset of high-fat diet-induced insulin resistance and obesity. Metabolism 2008, 57, 1071-1077. [CrossRef]

32. Magalhaes, D.A.; Kume, W.T.; Correia, F.S.; Queiroz, T.S.; Allebrandt Neto, E.W.; Santos, M.P.D.; Kawashita, N.H.; Franca, S.A. High-fat diet and streptozotocin in the induction of type 2 diabetes mellitus: A new proposal. An. Acad. Bras. Cienc. 2019, 91, e20180314. [CrossRef] [PubMed]

33. Surwit, R.S.; Kuhn, C.M.; Cochrane, C.; McCubbin, J.A.; Feinglos, M.N. Diet-induced type II diabetes in C57BL/6J mice. Diabetes 1988, 37, 1163-1167. [CrossRef] [PubMed]

34. Winzell, M.S.; Ahren, B. The high-fat diet-fed mouse: A model for studying mechanisms and treatment of impaired glucose tolerance and type 2 diabetes. Diabetes 2004, 53 (Suppl. 3), S215-S219. [CrossRef] [PubMed]

35. Leiter, E.H. Mice with targeted gene disruptions or gene insertions for diabetes research: Problems, pitfalls, and potential solutions. Diabetologia 2002, 45, 296-308. [CrossRef] [PubMed]

36. Ighodaro, O.M.; Adeosun, A.M.; Akinloye, O.A. Alloxan-induced diabetes, a common model for evaluating the glycemic-control potential of therapeutic compounds and plants extracts in experimental studies. Medicina 2017, 53, 365-374. [CrossRef] [PubMed]

37. Lenzen, S. The mechanisms of alloxan- and streptozotocin-induced diabetes. Diabetologia 2008, 51, 216-226. [CrossRef] [PubMed]

38. Coleman, D.L. Obese and diabetes: Two mutant genes causing diabetes-obesity syndromes in mice. Diabetologia 1978, 14, 141-148. [CrossRef] [PubMed] 
39. Wang, B.; Chandrasekera, P.C.; Pippin, J.J. Leptin- and leptin receptor-deficient rodent models: Relevance for human type 2 diabetes. Curr. Diabetes Rev. 2014, 10, 131-145. [CrossRef] [PubMed]

40. Trayhurn, P.; Thurlby, P.L.; James, W.P. Thermogenic defect in pre-obese ob/ob mice. Nature 1977, 266, 60-62. [CrossRef] [PubMed]

41. Coleman, D.L.; Hummel, K.P. The influence of genetic background on the expression of the obese (Ob) gene in the mouse. Diabetologia 1973, 9, 287-293. [CrossRef]

42. Sainz, N.; Rodriguez, A.; Catalan, V.; Becerril, S.; Ramirez, B.; Gomez-Ambrosi, J.; Fruhbeck, G. Leptin administration downregulates the increased expression levels of genes related to oxidative stress and inflammation in the skeletal muscle of ob/ob mice. Mediat. Inflamm. 2010, 2010, 784343. [CrossRef]

43. Fruhbeck, G.; Catalan, V.; Rodriguez, A.; Ramirez, B.; Becerril, S.; Portincasa, P.; Gomez-Ambrosi, J. Normalization of adiponectin concentrations by leptin replacement in ob/ob mice is accompanied by reductions in systemic oxidative stress and inflammation. Sci. Rep. 2017, 7, 2752. [CrossRef] [PubMed]

44. Salgado-Roman, J.M.; Loza-Cornejo, S.; Hernandez-Soto, R.; Hernandez-Maldonado, J.A.; Marquez-Villalobos, F.A.; PerezVazquez, V.; Franco-Robles, E.; Ramirez-Emiliano, J. Phytosterol Extract Decreases the Oxidative Damage in the Brains of Diabetic $\mathrm{db} / \mathrm{db}$ Mice. Metab. Syndr. Relat. Disord. 2021. [CrossRef] [PubMed]

45. Clark, J.B.; Palmer, C.J.; Shaw, W.N. The diabetic Zucker fatty rat. Proc. Soc. Exp. Biol. Med. 1983, 173, 68-75. [CrossRef]

46. Gustavsson, C.; Soga, T.; Wahlstrom, E.; Vesterlund, M.; Azimi, A.; Norstedt, G.; Tollet-Egnell, P. Sex-dependent hepatic transcripts and metabolites in the development of glucose intolerance and insulin resistance in Zucker diabetic fatty rats. J. Mol. Endocrinol. 2011, 47, 129-143. [CrossRef] [PubMed]

47. Raza, H.; John, A.; Howarth, F.C. Increased oxidative stress and mitochondrial dysfunction in zucker diabetic rat liver and brain. Cell Physiol. Biochem. 2015, 35, 1241-1251. [CrossRef]

48. Kawano, K.; Hirashima, T.; Mori, S.; Saitoh, Y.; Kurosumi, M.; Natori, T. Spontaneous long-term hyperglycemic rat with diabetic complications. Otsuka Long-Evans Tokushima Fatty (OLETF) strain. Diabetes 1992, 41, 1422-1428. [CrossRef]

49. Moran, T.H. Unraveling the obesity of OLETF rats. Physiol. Behav. 2008, 94, 71-78. [CrossRef] [PubMed]

50. Minamiyama, Y.; Takemura, S.; Kodai, S.; Shinkawa, H.; Tsukioka, T.; Ichikawa, H.; Naito, Y.; Yoshikawa, T.; Okada, S. Iron restriction improves type 2 diabetes mellitus in Otsuka Long-Evans Tokushima fatty rats. Am. J. Physiol. Endocrinol. Metab. 2010, 298, E1140-E1149. [CrossRef] [PubMed]

51. Movassat, J.; Saulnier, C.; Portha, B. Beta-cell mass depletion precedes the onset of hyperglycaemia in the GK rat, a genetic model of non-insulin-dependent diabetes mellitus. Diabetes Metab. 1995, 21, 365-370.

52. Portha, B. Programmed disorders of beta-cell development and function as one cause for type 2 diabetes? The GK rat paradigm. Diabetes Metab. Res. Rev. 2005, 21, 495-504. [CrossRef]

53. Goto, Y.; Kakizaki, M.; Masaki, N. Production of spontaneous diabetic rats by repetition of selective breeding. Tohoku J. Exp. Med. 1976, 119, 85-90. [CrossRef]

54. Kitamura, H. Effects of Propolis Extract and Propolis-Derived Compounds on Obesity and Diabetes: Knowledge from Cellular and Animal Models. Molecules 2019, 24, 4394. [CrossRef] [PubMed]

55. Infante-Garcia, C.; Garcia-Alloza, M. Review of the Effect of Natural Compounds and Extracts on Neurodegeneration in Animal Models of Diabetes Mellitus. Int. J. Mol. Sci 2019, 20, 2533. [CrossRef]

56. Yang, S.C.; Hsu, C.Y.; Chou, W.L.; Fang, J.Y.; Chuang, S.Y. Bioactive Agent Discovery from the Natural Compounds for the Treatment of Type 2 Diabetes Rat Model. Molecules 2020, 25, 5713. [CrossRef] [PubMed]

57. Fang, J.Y.; Lin, C.H.; Huang, T.H.; Chuang, S.Y. In Vivo Rodent Models of Type 2 Diabetes and Their Usefulness for Evaluating Flavonoid Bioactivity. Nutrients 2019, 11, 530. [CrossRef] [PubMed]

58. Spencer, J.P.; Abd El Mohsen, M.M.; Minihane, A.M.; Mathers, J.C. Biomarkers of the intake of dietary polyphenols: Strengths, limitations and application in nutrition research. Br. J. Nutr. 2008, 99, 12-22. [CrossRef] [PubMed]

59. Pandey, K.B.; Rizvi, S.I. Plant polyphenols as dietary antioxidants in human health and disease. Oxid. Med. Cell Longev. 2009, 2, 270-278. [CrossRef] [PubMed]

60. Tian, X.; Liu, Y.; Ren, G.; Yin, L.; Liang, X.; Geng, T.; Dang, H.; An, R. Resveratrol limits diabetes-associated cognitive decline in rats by preventing oxidative stress and inflammation and modulating hippocampal structural synaptic plasticity. Brain Res. 2016, 1650, 1-9. [CrossRef] [PubMed]

61. Sadi, G.; Konat, D. Resveratrol regulates oxidative biomarkers and antioxidant enzymes in the brain of streptozotocin-induced diabetic rats. Pharm. Biol. 2016, 54, 1156-1163. [CrossRef] [PubMed]

62. Corona, J.C.; Duchen, M.R. PPARgamma as a therapeutic target to rescue mitochondrial function in neurological disease. Free Radic. Biol. Med. 2016, 100, 153-163. [CrossRef]

63. Sarkar, P.; Bhowmick, A.; Kalita, M.C.; Banu, S. Effects of Resveratrol and Mangiferin on PPARgamma and FALDH Gene Expressions in Adipose Tissue of Streptozotocin-Nicotinamide-Induced Diabetes in Rats. J. Diet Suppl. 2019, 16, 659-675. [CrossRef]

64. Faheem, N.M.; El Askary, A. Neuroprotective role of curcumin on the hippocampus against the structural and serological alterations of streptozotocin-induced diabetes in Sprague Dawely rats. Iran. J. Basic Med. Sci. 2017, 20, 690-699. 
65. Lima, T.F.O.; Costa, M.C.; Figueiredo, I.D.; Inacio, M.D.; Rodrigues, M.R.; Assis, R.P.; Baviera, A.M.; Brunetti, I.L. Curcumin, Alone or in Combination with Aminoguanidine, Increases Antioxidant Defenses and Glycation Product Detoxification in Streptozotocin-Diabetic Rats: A Therapeutic Strategy to Mitigate Glycoxidative Stress. Oxid. Med. Cell Longev. 2020, 2020, 1036360. [CrossRef]

66. Rashedinia, M.; Alimohammadi, M.; Shalfroushan, N.; Khoshnoud, M.J.; Mansourian, M.; Azarpira, N.; Sabahi, Z. Neuroprotective Effect of Syringic Acid by Modulation of Oxidative Stress and Mitochondrial Mass in Diabetic Rats. Biomed. Res. Int. 2020, 2020, 8297984. [CrossRef]

67. Mahesh, T.; Menon, V.P. Quercetin allievates oxidative stress in streptozotocin-induced diabetic rats. Phytother. Res. 2004, 18, 123-127. [CrossRef]

68. Coskun, O.; Kanter, M.; Korkmaz, A.; Oter, S. Quercetin, a flavonoid antioxidant, prevents and protects streptozotocin-induced oxidative stress and beta-cell damage in rat pancreas. Pharmacol. Res. 2005, 51, 117-123. [CrossRef]

69. Roslan, J.; Giribabu, N.; Karim, K.; Salleh, N. Quercetin ameliorates oxidative stress, inflammation and apoptosis in the heart of streptozotocin-nicotinamide-induced adult male diabetic rats. Biomed. Pharmacother. 2017, 86, 570-582. [CrossRef] [PubMed]

70. Gaballah, H.H.; Zakaria, S.S.; Mwafy, S.E.; Tahoon, N.M.; Ebeid, A.M. Mechanistic insights into the effects of quercetin and/or GLP-1 analogue liraglutide on high-fat diet/streptozotocin-induced type 2 diabetes in rats. Biomed. Pharmacother. 2017, 92, 331-339. [CrossRef] [PubMed]

71. Suganya, N.; Dornadula, S.; Chatterjee, S.; Mohanram, R.K. Quercetin improves endothelial function in diabetic rats through inhibition of endoplasmic reticulum stress-mediated oxidative stress. Eur. J. Pharmacol. 2018, 819, 80-88. [CrossRef]

72. Hu, T.; Shi, J.J.; Fang, J.; Wang, Q.; Chen, Y.B.; Zhang, S.J. Quercetin ameliorates diabetic encephalopathy through SIRT1/ER stress pathway in $\mathrm{db} / \mathrm{db}$ mice. Aging 2020, 12, 7015-7029. [CrossRef] [PubMed]

73. Zhang, Q.; Song, W.; Zhao, B.; Xie, J.; Sun, Q.; Shi, X.; Yan, B.; Tian, G.; Liang, X. Quercetin Attenuates Diabetic Peripheral Neuropathy by Correcting Mitochondrial Abnormality via Activation of AMPK/PGC-1alpha Pathway in vivo and in vitro. Front. Neurosci. 2021, 15, 636172. [CrossRef]

74. Al-Numair, K.S.; Chandramohan, G.; Veeramani, C.; Alsaif, M.A. Ameliorative effect of kaempferol, a flavonoid, on oxidative stress in streptozotocin-induced diabetic rats. Redox. Rep. 2015, 20, 198-209. [CrossRef]

75. Chen, X.; Qian, J.; Wang, L.; Li, J.; Zhao, Y.; Han, J.; Khan, Z.; Wang, J.; Liang, G. Kaempferol attenuates hyperglycemia-induced cardiac injuries by inhibiting inflammatory responses and oxidative stress. Endocrine 2018, 60, 83-94. [CrossRef] [PubMed]

76. Liu, Y.; Tian, X.; Gou, L.; Sun, L.; Ling, X.; Yin, X. Luteolin attenuates diabetes-associated cognitive decline in rats. Brain Res. Bull. 2013, 94, 23-29. [CrossRef] [PubMed]

77. Nurdiana, S.; Goh, Y.M.; Hafandi, A.; Dom, S.M.; Nur Syimal'ain, A.; Noor Syaffinaz, N.M.; Ebrahimi, M. Improvement of spatial learning and memory, cortical gyrification patterns and brain oxidative stress markers in diabetic rats treated with Ficus deltoidea leaf extract and vitexin. J. Tradit. Complement. Med. 2018, 8, 190-202. [CrossRef] [PubMed]

78. Abdel-Rahman, R.F.; Ezzat, S.M.; Ogaly, H.A.; Abd-Elsalam, R.M.; Hessin, A.F.; Fekry, M.I.; Mansour, D.F.; Mohamed, S.O. Ficus deltoidea extract down-regulates protein tyrosine phosphatase $1 \mathrm{~B}$ expression in a rat model of type 2 diabetes mellitus: A new insight into its antidiabetic mechanism. J. Nutr. Sci. 2020, 9, e2. [CrossRef]

79. Li, R.; Zang, A.; Zhang, L.; Zhang, H.; Zhao, L.; Qi, Z.; Wang, H. Chrysin ameliorates diabetes-associated cognitive deficits in Wistar rats. Neurol. Sci. 2014, 35, 1527-1532. [CrossRef]

80. Satyanarayana, K.; Sravanthi, K.; Shaker, I.A.; Ponnulakshmi, R.; Selvaraj, J. Role of chrysin on expression of insulin signaling molecules. J. Ayurveda Integr. Med. 2015, 6, 248-258. [CrossRef] [PubMed]

81. Fuliang, H.U.; Hepburn, H.R.; Xuan, H.; Chen, M.; Daya, S.; Radloff, S.E. Effects of propolis on blood glucose, blood lipid and free radicals in rats with diabetes mellitus. Pharmacol. Res. 2005, 51, 147-152. [CrossRef]

82. Shi, Y.Z.; Liu, Y.C.; Zheng, Y.F.; Chen, Y.F.; Si, J.J.; Chen, M.L.; Shou, Q.Y.; Zheng, H.Q.; Hu, F.L. Ethanol Extract of Chinese Propolis Attenuates Early Diabetic Retinopathy by Protecting the Blood-Retinal Barrier in Streptozotocin-Induced Diabetic Rats. J. Food Sci. 2019, 84, 358-369. [CrossRef]

83. Zhu, W.; Chen, M.; Shou, Q.; Li, Y.; Hu, F. Biological activities of chinese propolis and brazilian propolis on streptozotocin-induced type 1 diabetes mellitus in rats. Evid Based Complement. Alternat. Med. 2011, 2011, 468529. [CrossRef]

84. Orsolic, N.; Sirovina, D.; Koncic, M.Z.; Lackovic, G.; Gregorovic, G. Effect of Croatian propolis on diabetic nephropathy and liver toxicity in mice. BMC Complement. Altern. Med. 2012, 12, 117. [CrossRef]

85. Nna, V.U.; Abu Bakar, A.B.; Md Lazin, M.; Mohamed, M. Antioxidant, anti-inflammatory and synergistic anti-hyperglycemic effects of Malaysian propolis and metformin in streptozotocin-induced diabetic rats. Food Chem. Toxicol. 2018, 120, 305-320. [CrossRef]

86. Chen, L.H.; Chien, Y.W.; Chang, M.L.; Hou, C.C.; Chan, C.H.; Tang, H.W.; Huang, H.Y. Taiwanese Green Propolis Ethanol Extract Delays the Progression of Type 2 Diabetes Mellitus in Rats Treated with Streptozotocin/High-Fat Diet. Nutrients 2018, 10, 503. [CrossRef]

87. Rivera-Yanez, N.; Rodriguez-Canales, M.; Nieto-Yanez, O.; Jimenez-Estrada, M.; Ibarra-Barajas, M.; Canales-Martinez, M.M.; Rodriguez-Monroy, M.A. Hypoglycaemic and Antioxidant Effects of Propolis of Chihuahua in a Model of Experimental Diabetes. Evid. Based Complement. Alternat. Med. 2018, 2018, 4360356. [CrossRef] 
88. Sorrenti, V.; Raffaele, M.; Vanella, L.; Acquaviva, R.; Salerno, L.; Pittala, V.; Intagliata, S.; Di Giacomo, C. Protective Effects of Caffeic Acid Phenethyl Ester (CAPE) and Novel Cape Analogue as Inducers of Heme Oxygenase-1 in Streptozotocin-Induced Type 1 Diabetic Rats. Int. J. Mol. Sci. 2019, 20, 2441. [CrossRef]

89. Zhou, J.Y.; Zhou, S.W. Protective effect of berberine on antioxidant enzymes and positive transcription elongation factor $b$ expression in diabetic rat liver. Fitoterapia 2011, 82, 184-189. [CrossRef]

90. Chatuphonprasert, W.; Lao-Ong, T.; Jarukamjorn, K. Improvement of superoxide dismutase and catalase in streptozotocinnicotinamide-induced type 2-diabetes in mice by berberine and glibenclamide. Pharm. Biol. 2013. [CrossRef]

91. Liu, C.; Wang, Z.; Song, Y.; Wu, D.; Zheng, X.; Li, P.; Jin, J.; Xu, N.; Li, L. Effects of berberine on amelioration of hyperglycemia and oxidative stress in high glucose and high fat diet-induced diabetic hamsters in vivo. Biomed. Res. Int. 2015, $2015,313808$. [CrossRef]

92. Wang, S.; He, B.; Hang, W.; Wu, N.; Xia, L.; Wang, X.; Zhang, Q.; Zhou, X.; Feng, Z.; Chen, Q.; et al. Berberine Alleviates Tau Hyperphosphorylation and Axonopathy-Associated with Diabetic Encephalopathy via Restoring PI3K/Akt/GSK3beta Pathway. J. Alzheimers Dis. 2018, 65, 1385-1400. [CrossRef] [PubMed]

93. Oguntibeju, O.O.; Aboua, Y.; Goboza, M. Vindoline-A Natural Product from Catharanthus Roseus Reduces Hyperlipidemia and Renal Pathophysiology in Experimental Type 2 Diabetes. Biomedicines 2019, 7, 59. [CrossRef]

94. Goboza, M.; Aboua, Y.G.; Chegou, N.; Oguntibeju, O.O. Vindoline effectively ameliorated diabetes-induced hepatotoxicity by docking oxidative stress, inflammation and hypertriglyceridemia in type 2 diabetes-induced male Wistar rats. Biomed. Pharmacother. 2019, 112, 108638. [CrossRef]

95. Guo, C.; Han, F.; Zhang, C.; Xiao, W.; Yang, Z. Protective effects of oxymatrine on experimental diabetic nephropathy. Planta Med. 2014, 80, 269-276. [CrossRef]

96. Tian, Z.; Ren, N.; Wang, J.; Zhang, D.; Zhou, Y. Ginsenoside Ameliorates Cognitive Dysfunction in Type 2 Diabetic Goto-Kakizaki Rats. Med. Sci. Monit. 2018, 24, 3922-3928. [CrossRef] [PubMed]

97. Hossain, M.A.; Lee, D.; Kim, B.; Kang, C.W.; Kim, N.S.; Kim, J.H. Korean Red Ginseng attenuates type 2 diabetic cardiovascular dysfunction in Otsuka Long-Evans Tokushima Fatty rats. J. Ginseng Res. 2020, 44, 308-311. [CrossRef] [PubMed]

98. Pivari, F.; Mingione, A.; Brasacchio, C.; Soldati, L. Curcumin and Type 2 Diabetes Mellitus: Prevention and Treatment. Nutrients 2019, 11, 1837. [CrossRef]

99. Corona, J.C.; Duchen, M.R. PPARgamma and PGC-1alpha as therapeutic targets in Parkinson's. Neurochem. Res. 2015, 40, 308-316. [CrossRef]

100. Alvarez-Arellano, L.; Salazar-Garcia, M.; Corona, J.C. Neuroprotective Effects of Quercetin in Pediatric Neurological Diseases. Molecules 2020, 25, 5597. [CrossRef]

101. Silva Dos Santos, J.; Goncalves Cirino, J.P.; de Oliveira Carvalho, P.; Ortega, M.M. The Pharmacological Action of Kaempferol in Central Nervous System Diseases: A Review. Front. Pharmacol. 2020, 11, 565700. [CrossRef] [PubMed]

102. Omar, M.H.; Mullen, W.; Crozier, A. Identification of proanthocyanidin dimers and trimers, flavone C-Glycosides, and antioxidants in Ficus deltoidea, a malaysian herbal tea. J. Agric. Food Chem. 2011, 59, 1363-1369. [CrossRef]

103. Khalil, M.L. Biological activity of bee propolis in health and disease. Asian Pac. J. Cancer Prev. 2006, 7, $22-31$.

104. Qiu, S.; Sun, H.; Zhang, A.H.; Xu, H.Y.; Yan, G.L.; Han, Y.; Wang, X.J. Natural alkaloids: Basic aspects, biological roles, and future perspectives. Chin. J. Nat. Med. 2014, 12, 401-406. [CrossRef]

105. Kumar, A.; Ekavali; Chopra, K.; Mukherjee, M.; Pottabathini, R.; Dhull, D.K. Current knowledge and pharmacological profile of berberine: An update. Eur. J. Pharmacol. 2015, 761, 288-297. [CrossRef]

106. Shishtar, E.; Sievenpiper, J.L.; Djedovic, V.; Cozma, A.I.; Ha, V.; Jayalath, V.H.; Jenkins, D.J.; Meija, S.B.; de Souza, R.J.; Jovanovski, E.; et al. The effect of ginseng (the genus panax) on glycemic control: A systematic review and meta-analysis of randomized controlled clinical trials. PLoS ONE 2014, 9, e107391. [CrossRef]

107. Hokayem, M.; Blond, E.; Vidal, H.; Lambert, K.; Meugnier, E.; Feillet-Coudray, C.; Coudray, C.; Pesenti, S.; Luyton, C.; LambertPorcheron, S.; et al. Grape polyphenols prevent fructose-induced oxidative stress and insulin resistance in first-degree relatives of type 2 diabetic patients. Diabetes Care 2013, 36, 1454-1461. [CrossRef]

108. Mang, B.; Wolters, M.; Schmitt, B.; Kelb, K.; Lichtinghagen, R.; Stichtenoth, D.O.; Hahn, A. Effects of a cinnamon extract on plasma glucose, $\mathrm{HbA}$, and serum lipids in diabetes mellitus type 2. Eur. J. Clin. Investig. 2006, 36, 340-344. [CrossRef]

109. Taj Eldin, I.M.; Ahmed, E.M.; Elwahab, H.M.A. Preliminary Study of the Clinical Hypoglycemic Effects of Allium cepa (Red Onion) in Type 1 and Type 2 Diabetic Patients. Environ. Health Insights 2010, 4, 71-77.

110. Choi, H.C.; Kim, S.J.; Son, K.Y.; Oh, B.J.; Cho, B.L. Metabolic effects of aloe vera gel complex in obese prediabetes and early non-treated diabetic patients: Randomized controlled trial. Nutrition 2013, 29, 1110-1114. [CrossRef] 